Volume 15. Nomor 1. June 2020 Page 74-82
Pandecta
http://journal.unnes.ac.id/nju/index.php/pandecta

\title{
Hak Perempuan dan Kesetaraan Gender dalam Perspektif Filsafat Hukum
}

\author{
Budi Hermawan Bangun ${ }^{1}$
}

1Fakultas Hukum Universitas Tanjungpura, Indonesia

DOI: http://dx.doi.org/10.15294/pandecta.v15i1.23895

\begin{abstract}
Article info
Abstrak

Article History:

Received: April 12020

Tulisan ini berfokus pada asal mula dan perkembangan hak perempuan dan prinsip kesetaraan gender dalam perspektif filsafat hukum. Hak perempuan sebagai bagian Accepted: May 102020 Published: June 152020 dari Hak Asasi Manusia lahir dan berkembang dari pemikiran-pemikiran mengenai pentingnya perlindungan dan pemenuhan hak bagi kaum perempuan yang termas-

Keywords:

filsafat hukum;

hak perempuan;

kesetaraan gender uk kelompok rentan dan juga untuk memastikan kesetaraan gender. Meskipun telah diakomodasi dalam berbagai instrumen hukum nasional maupun internasional, namun secara de facto pemenuhan hak perempuan seca masih harus dipastikan oleh setiap negara. Pemenuhan hak perempuan dalam perspektif filsafat hukum adalah upaya untuk mendapatkan keadilan sebagai tujuan tertinggi dari hukum itu sendiri

legal philosopy; women's rights, gender equality dan memastikan terwujudnya prinsip equality before the law.

Abstract

This paper focuses on the origin and development of women's rights and the principle of gender equality in the perspective of legal philosophy. Women's rights as part of Human Rights were born and developed from thoughts about the importance of protecting and fulfilling the rights of women who belong to vulnerable groups and also to ensure gender equality. Although it has been accommodated in various national and international legal instruments, de facto fulfillment of women's rights must still be ensured by each country. Fulfillment of women's rights in the perspective of legal philosophy seeks to obtain justice as the highest goal of the law itself and ensure the realization of the principle of equality before the law.
\end{abstract}




\section{Pendahuluan}

Negara Indonesia mengakui dan menjunjung tinggi hak asasi manusia (HAM) dan kebebasan dasar manusia sebagai hak yang secara kodrati melekat pada manusia, yang harus dilindungi, dihormati, dan ditegakkan demi meningkatkan martabat kemanusiaan, kesejahteraan, kebahagiaan, dan kecerdasan serta keadilan. Hal tersebut diatur dalam Undang-Undang Dasar Republik Indonesia Tahun 1945 dan berbagai peraturan perundang-undangan lainnya seperti Undang-Undang No. 39 Tahun 1999 tentang Hak Asasi Manusia. Selain itu pula, Indonesia telah mengesahkan berbagai perjanjian internasional yang berkaitan dengan HAM seperti International Convention of Civil and Political Rights (ICCPR) melalui Undang-Undang No. 12 Tahun 2005 dan International Convention of Economic, Social and Cultural Rights (ICESCR) melalui Undang-Undang No. $11 \mathrm{Ta}-$ hun 2005.

Salah satu jenis hak yang diakui secara nasional maupun internasional adalah hak asasi perempuan yang selanjutnya akan disebut dengan hak perempuan. Hak perempuan hak yang dimiliki oleh seorang perempuan, baik karena ia seorang manusia maupun sebagai seorang perempuan, dalam khasanah hukum hak asasi manusia dapat ditemui pengaturannya dalam berbagai sistem hukum tentang hak asasi manusia. Sistem ini meliputi berbagai instrumen hukum dan perangkat pelaksanaan sistem hukum baik di tingkat nasional, regional maupun internasional. Berbagai sistem tersebut tidak saja mencantumkan hak yang diakui namun juga bagaimana menjamin dan mengakses hak tersebut (Eddyono, 2020).

Di Indonesia pengaturan tentang hak perempuan dapat ditemui dalam Pasal 45-51 UU No. 39 Tahun 1999 dan juga undang-undang lainnya yang berhubungan erta dengan hak perempuan seperti UU No. 23 Tahun 2004 tentang Pemghapusan Kekerasan dalam Rumah Tangga. Selain itu Indonesia juga telah meratifikasi sejumlah perjanjian internasional yang berkenaan dengan hak perempuan seperti: Convention on the Elimination of all Forms of Discrimination Against Women
(CEDAW) melalui UU No. 7 Tahun 1984. Secara kelembagaan, Indonesia juga telah membentuk Komisi Nasional Anti Kekerasan Terhadap Perempuan (Komnas Perempuan) melalui Peraturan Presiden No. 181 Tahun 1998 tanggal 9 Oktober 1998 yang kemudian diperkuat dengan Peraturan Presiden No. 65 Tahun 2005.

Dalam berbagai kajian dan pengaturan dari instrumen hukum nasional dan hukum internasional, perempuan dimasukkan ke dalam kelompok rentan (vulnerable) bersamasama dengan kelompok rentan lainnya seperti anak-anak, kaum minoritas, pengungsi dan lainnya. Masuknya perempuan sebagai salah satu kelompok rentan dalam HAM adalah karena berbagai kondisi sosial, budaya, ekonomi ataupun secara fisik yang menyebabkan perempuan sebagai kelompok yang lemah dan tak terlindungi dan karenanya berada dalam resiko dan bahaya mengalami kekerasan atau pelanggaran hak oleh kelompok lainnya (Krisnalita, 2018: 75).

Hak perempuan sendiri mencakup berbagai jenis hak yang cakupannya cukup luas seperti (Krisnalita, 2018: 76-77):

1. Hak-hak di bidang politik, antara lain: Hak untuk berpartisipasi dalam pemerintahan dengan ikut serta dalam perumusan kebijakan pemerintah dan pelaksanaan kebijakan; Hak untuk dipilih dan memilih dalam pemilihan berkala yang bebas untuk menentukan wakil rakyat di pemerintahan; dan Hak untuk ambil bagian dalam organisasiorganisasi pemerintahan dan non pemerintahan dan himpunanhimpunan yang berkaitan dengan kehidupan pemerintahan dan politik negara tersebut.

2. Hak-hak kewarganegaraan. Setiap perempuan mempunyai hak yang sama untuk mendapatkan kewarganegaraan suatu negara ketika mereka dapat memenuhi syarat-syarat yang ditentukan oleh peraturan perundangundangan di negara terkait.

3. Hak atas pendidikan dan pengajaran.

4. Hak atas pekerjaan.

5. Hak di bidang kesehatan. 
6. Hak untuk melakukan perbuatanperbuatan hukum.

Dalam upaya untuk mewujudkan pemenuhan hak perempuan, salah satu prinsip yang diperkenalkan dan dikembangkan adalah prinsip kesetaraan gender. Istilah gender sendiri diperkenalkan oleh para ilmuwan sosial untuk menjelaskan perbedaan perempuan dan laki-laki yang bersifat kodrati dan yang merupakan hasil bentukan budaya (Hasanah \& Musyafak, 2017: 413). Dalam perkembangan selanjutnya, istilah ini selalu dikaitkan dengan budaya dengan menunjuk kepada perbedaan status dan peranan lakilaki dan perempuan yang terbentuk dalam proses sosial dan budaya yang panjang (Sinulingga, 2006: 47).

Prinsip kesetaraan gender ditandai dengan kondisi bagi laki-laki dan perempuan untuk memperoleh kesempatan serta hakhaknya sebagai manusia, agar mampu berperan dan berpartisipasi dalam kegiatan politik, hukum, ekonomi, sosial budaya, pendidikan dan pertahanan dan keamanan nasional serta kesamaan dalam menikmati hasil pembangunan. Kesetaraan gender juga meliputi meliputi penghapusan diskriminasi dan ketidak adilan struktural, baik terhadap laki-laki maupun perempuan.

Di berbagai tempat, termasuk Indonesia muncul diskursus mengenai prinsip kesetaraan gender ini. Hal tersebut dapat dipahami karena setiap konsep, produk pemikiran serta teori keilmuan sesungguhnya merupakan hasil dari pandangan hidup (worldview). Tulisan ini hendak mengulas tentang hak perempuan dan pemikiran atau prinsip kesetaraan gender dalam perspektif filsafat hukum. Sistematika tulisan ini dimulai dengan pendahuluan dan dilanjutkan dengan pembahasan yang berisi pejelasan mengenai asal mula dan perkembangan hak perempuan dan dilanjutkan dengan kesetaraan gender dalam perspektif filsafat hukum sebelum akhirnya ditutup dengan kesimpulan.

\section{Hasil dan Pembahasan}

\section{Hak Perempuan: Asal Mula dan Perkem- bangannya}

Pengakuan dan jaminan pemenuhan hak perempuan tumbuh dan berkembang bersamaan dengan pemahaman konsep HAM itu sendiri. Asumsi dasar dalam konsep HAM adalah setiap manusia sejatinya memiliki hak kodrati yang harus dihormati dan dilindungi untuk menjaga harkat dan martabat dari kehidupan manusia tersebut.

Dalam kenyataannya, seringkali perempuan diposisikan tidak setara dengan laki-laki. Perbedaan biologis, munculnya stereotype, dominasi sosiologis laki-laki terhadap perempuan (budaya patriarki) dan bahkan praktik-praktik keagamaan telah melahirkan diskriminasi yang membuat perempuan sebagai kelompok rentan terhadap pelanggaran HAM. Munculnya kesadaran bahwa perempuan merupakan manusia yang memiliki derajat yang sama dengan laki-laki telah memicu melahirkan konseptualisasi terhadap hak-hak khusus sebagai bagian dari HAM yaitu hak perempuan.

Tonggak sejarah dari lahirnya kesadaran mengenai hak perempuan ini bisa jadi berbeda di satu tempat dengan tempat lainnya. Dalam sejarah modern Indonesia misalnya, R.A. Kartini dikenal sebagai salah seorang tokoh yang mendorong emansipasi perempuan. Melalui surat-surat yang dikirimkannya kepada rekannya di Belanda, Kartini menceritakan harapannya akan emansipasi antara perempuan dan laki-laki, kebebasan berpikir bagi kaum perempuan dan hal-hal lain yang telah membuka diskursus mengenai hak perempuan, meskipun konsep HAM pada waktu itu masih sumir (Asmarani, 2017). Sementara itu di Inggris hak-hak perempuan diperjuangkan sejak abad 18 oleh Mary Wollstonecraft yang melahirkan konsep "feminisme". Feminisme menurut Wollstonecraft berperspektif pada kurangnya pendidikan pada perempuan, sehingga mereka tidak mampu untuk melaksanakan hak-haknya yang tertinggal dari kaum laki-laki (Saparjaya, 2006: 7).

Secara internasional, usaha untuk membangun konsepsi mengenai hak perempuan dimulai oleh Liga Bangsa-Bangsa (LBB) setelah berakhirnya Perang Dunia I. Pada tahun 1935 mulai dibahas kedudukan perempuan, dan mempertimbangkannya 
dari aspek-aspek sipil dan politik (Handayani, 2020). Berlanjut setelah Perang Dunia II berakhir, Piagam Perserikatan Bangsa (PBB) merupakan instrumen internasional pertama yang menyebutkan persamaan hak antara laki-laki dan perempuan (Handayani, 2020). Melalui tubuh PBB juga, komitmen internasional untuk mengakui dan melindungi HAM ditunjukkan melalui Deklarasi Universal HAM (DUHAM) pada tanggal 10 Desember 1948.

Setelah DUHAM, lahir berbagai instrumen HAM internasional yang secara umum maupun khusus berkenaan dengan hak dan perlindungan bagi perempuan dalam berbagai aspek kehidupan, seperti: Convention for the Suppression of the Traffic in Persons and of the Exploitation of the Prostitution of Others (1949), ILO (No. 100) Equal Remuneration Convention (1951), Convention on the Political Rights of Women (1952) yang diratifikasi Indonesia melalui UU No. 68 Tahun 1956, Declaration on the Protection of Women and Children in Emergency and Armed Conflict (1974), dan Convention on the Consent to Marriage, Minimum Age for Marriage an Registration of Marriages (1962).

Di tahun 70-an, isu mengenai hak perempuan semakin mengemuka. Pada tahun 1975, sebuah Konferensi Dunia Tahun Perempuan Internasional (World Conference of the International Women's Year) diadakan di Mexico City yang menghasilkan Declaration of Mexico on the Equality of Women and Their Contribution to Development and Peace. Konferensi tersebut mempunyai arti penting karena meletakkan prinsip-prinsip mendasar dari kehidupan perempuan sekaligus mengakomodasi permassalahan yang dihadapi perempuan.

Pada tanggal 18 Desember 1979, Majelis Umum PBB menyetujui rancangan CEDAW dan mengundang negara-negara anggota PBB untuk meratifikasinya. Konvensi ini kemudian mulai berlaku (entry into force) pada tahun 1981 setelah 20 negara menyetujuinya. Berlakunya CEDAW dapat dikatakan sebagai langkah maju yang paling penting untuk mencegah diskriminasi terhadap perempuan sekaligus upaya untuk memenuhi hak perempuan. CEDAW merupakan perjanjian internasional mengenai hak perempuan yang paling komprehensif karena menetapkan kewajiban yang mengikat kepada negara peserta untuk secara hukum mengakhiri diskriminasi terhadap perempuan melalui berbagai langkah, program dan kebijakan serta mendorong negara-negara peserta untuk menyatakan persamaan antara laki-laki dan perempuan dalam bidang hak-hak politik, ekonomi, sosial dan budaya. Hal ini dimungkinkan karena CEDAW secara aktif melakukan perbaikan bahasa-bahasa hukum yang secara tegas memihak kepada hak perempuan yang karena itu dapat menunjukkan dan memantapkan peranan pergerakan perempuan dalam implementasi dari CEDAW itu sendiri (Arivia, 2006: 311).

Usaha untuk mewujudkan hak perempuan sebagai bagian HAM yang universal terus berlanjut setelah CEDAW. Pada tahun 1980 Konferensi Dunia tentang Perempuan II diselenggarakan di Copenhagen dan dilajutkan di Nairobi pada tahun 1985 dan di Beijing pada tahun 1995. Aktivitas ini berdampak pada kelompok-kelompok HAM internasional di PBB. Konferensi di Beijing sendiri menghasilkan Beijing Plattform for Action (BPFA) yang mengkritisi 12 area kritis yang dihadapi oleh kaum perempuan di seluruh dunia seperti hak-hak di bidang pendidikan, kesehatan dan ketenagakerjaan (Saparjaya, 2006: 2).

Sebelum BPFA, dalam Konferensi Internasional HAM yang dilaksanakan di Wina pada bulan Juni 1993 telah menghasilkan Vienne Declaration and Platform Action yang menekankan agar hak perempuan harus menjadi bagian yang integral dari seluruh aktivitas dan setiap instrumen HAM dan mendorong intesifikasi upaya untuk mendorong pengakuan dan perlindungan hak perempuan.

Berbagai hasil pertemuan dan kerangka aksi tersebut pada akhirnya juga telah mendorong pemaknaan ulang terhadap instrumen-instrumen HAM yang telah dihasilkan sebelumnya. Beberapa mekanisme HAM PBB yang berdasar kepada pada perjanjian internasional melakukan adopsi dengan 
mengeluarkan komentar atau rekomendasi umum untuk mengkaji ulang persamaan hak antara perempuan dan laki-laki, yaitu (Handayani, 2020):

1. Komite HAM untuk Hak Sipil dan Politik mengeluarkan General Comment No. 28 (2000): Equality of Rights Between Men and Women tanggal 29 Maret 2000. Melalui Komentar Umum ini, komite menegaskan bahwa setiap negara yang sudah meratifikasi konvensi hak sipil dan politik, tidak saja harus mengadopsi langkah-langkah perlindungan tapi juga langkah-langkah posiitf di seluruh area untuk mencapai pemberdayaan perempuan yang setara dan efektif. Langkah ini termasuk pula penjaminan bahwa praktek-praktek tradisi, sejarah, agama, dan budaya tidak digunakan untuk menjustifikasi pelanggaran hak perempuan.

2. Komite tentang Penghapusan Segala Bentuk Diskriminasi Terhadap Perempuan mengeluarkan General Recommendation No. 25 (2004) yang meletakkan kerangka langkahlangkah khusus sementara (temporary special measures) untuk penghapusan diskriminasi langsung dan tidak langsung (direct and indirect discrimination) yang terjadi terhadap perempuan yang sangat mempengaruhi penikmatan perempuan. Bagi komite, posisi perempuan yang kerapkali tidak menguntungkan perlu disikapi dengan pendekatan persamaan hasil (equality of result) sebagai tujuan dari persamaan secara substantif (substantive equality) atau de facto tidak saja persamaan secara formal (formal equality).

3. Komite tentang Hak Ekonomi, Sosial dan Budaya mengeluarkan General Comment No.16 (2005): The Equal Rights of Men and Womento Enjoyment of All Economic, Social and Cultural Rights yang meletakkan kerangka tentang persamaan (equality), non diskriminasi (non discrimination) dan langkahlangkah sementara (temperature measure) yang menjadi acuan bagai para negara yang terikat dengan Konvenan Hak Ekonomi, Sosial, dan Budaya.

Di Indonesia sendiri komitmen untuk melindungi dan memenuhi hak perempuan ditunjukkan dengan ratifikasi berbagai instrumen internasional seperti CEDAW, CPRW, ICCPR dan ICESCR serta dengan membuat legislasi nasional yang mengandung muatan perlindungan hak perempuan seperti: UU No. 39 Tahun 1999 tentang HAM, UU No. 23 Tahun 2004 tentang Penghapusan KDRT, UU No. 12 Tahun 2006 tentang Kewarganegaraan, UU No. 21 Tahun 2007 tentang Pemberantasan Tindak Pidana Perdagangan Orang, Inpres No. 9 Tahun 2000 tentang Pengarustamaan Gender (PUG) dan Keppres No. 181 Tahun 1998 tentang Pembentukan Komisi Nasional Anti Kekerasan terhadap Perempuan atau Komnas Perempuan yang diubah dengan Perpres Nomor 65 Tahun 2005 (Kania, 2015: 718). Meskipun demikian, masih terdapat peraturan perundang-undangan yang belum berpihak kepada perempuan dan cenderung diskriminatif seperti ketentuan-ketentuan yang berkaitan dengan kejahatan seksual yang dikategorikan sebagai kejahatan terhadap kesusilaan dan bukan kejahatan terhadap integritas tubuh perempuan (Savitri, 2008: 104). Demikian pula terdapat Peraturan Daerah (Perda) di beberapa daerah yang cenderung tidak berpihak kepada perempuan. Dalam catatan Komnas Perempuan hingga akhir tahun 2018 yang lalu, di seluruh Indonesia terdapat 421 Perda yang substasinya dinilai diskriminatif terhadap perempuan.

Selain secara substansi hukum, dari segi struktur hukum juga masih sering ditemui lemahnya pemahaman isntitusi penegak manakala menangani kasus-kasus yang berkaitan dengan perempuan sebagai korban kekerasan, sementara dari segi budaya hukum cara pandang masyarakat yang lebih peduli terhadap hak-hak perempuan masih perlu dibangun (Kania, 2015: 731).

Dengan dikeluarkannya berbagai instrumen hukum nasional dan internasional masih belum menjamin sepenuhnya perempuan terlindungi dari pelanggaran hakhaknya. Budaya patriarki yang mendominasi 
negara-negara di dunia sedikit banyak berpengaruh pada pelaksanaan instrumen-instrumen hukum internasional yang berkaitan dengan hak perempuan. Dalam konteks Indonesia, kondisi sosial budaya serta kurangnya pemahaman dari pelaksana hukum menyebabkan masih ada beberapa persoalan bagi perempuan dalam memperoleh acces to justice, misalnya hak ekonomi (Widiarty, 2017), hak atas pekerjaan (Flambonita, 2017), dan hak atas pendidikan (Nasir \& Lilianti, 2017) Karena itu, negara sebagai penjaga HAM bagi setiap warganya harus menjamin perolehan hak-hak, termasuk hak perempuan, bukan saja secara de jure namun yang terpenting adalah secara de facto.

\section{Kesetaraan Gender dalam Perspektif Filsa- fat (Hukum)}

Hukum mempunyai tujuan untuk mewujudkan tata tertib dalam masyarakat dan kepastian hukum, akan tetapi secara filsafati ada tujuan yang jauh lebih penting lagi yang menjadi tujuan hukum yaitu keadilan. Dalam istilah "keadilan" terdapat istilah "adil" yang menjadi kata dasarnya. Kamus Besar Indonesia, adil diartikan sebagai: (1). sama berat; tidak berat sebelah; tidak memihak; (2). berpihak kepada yang benar; berpegang pada kebenaran; (3). sepatutnya; tidak sewenang-wenang. Berdasarkan pengertian tersebut, untuk disebut adil maka hukum harus memenuhi unsur-unsur, yaitu: sama, tidak memihak, berpegang pada kebenaran, dan tidak sewenang-wenang. Unsur pertama menurut penulis lebih tepat dikatakan seimbang daripada sama. Keadilan adalah sifat, perbuatan, dan perlakuan yang adil. Dikaitkan dengan pengertian adil, maka keadilan dapat diartikan sifat, perbuatan, dan perlakuan yang seimbang/sama, tidak memihak, berpegang pada kebenaran, dan tidak sewenang-wenang.

Persoalan keadilan merupakan masalah yang telah ada sejak zaman Yunani Kuno dan Romawi. Keadilan dianggap sebagai salah satu kebajikan utama (cardinal virtue) (Marzuki, 2016: 27). Bahkan menurut Aristoteles, hukum dikatakan memiliki tujuan semata-mata untuk mewujudkan keadilan (Machmudin, 2003: 23).
Keterkaitan hukum dan keadilan juga dipaparkan oleh John Rawls dengan menyebut bahwa keadilan yang berbasis hukum dan sifatnya administratif-formalnya sekalipun, tetaplah penting. Pada dasarnya paparan itu memberikan jaminan minimum bahwa setiap orang dalam kasus yang sama harus diperlakukan secara sama (Ujan, 2001: 27).

Lahirnya tuntutan atas pemenuhan dan perlindungan hak perempuan didasari oleh kondisi ketidakdilan yang dialami oleh perempuan itu sendiri. Karenanya isu dan gerakan kesetaraan gender, sebagai upaya untuk memperoleh pemenuhan dan perlindungan hak perempuan tidak bisa dilepaskan dari pemikiran-pemikiran mengenai keadilan itu sendiri. Salah satu pemikiran yang paling berpengaruh terhadap lahir dan berkembangnya hak perempuan adalah feminisme. Secara sederhana feminisme dapat diartikan sebagai paham, kajian dan gerakan sosial yang bertujuan untuk mengubah status subordinatif perempuan dalam masyarakat yang mengutamakan perspektif laki-laki (Suwastini, 2013: 199). Feminisme pada tahap awal terjadi antara tahun 1500-1700an dengan fokus untuk melawan pandangan patriarkis mengenai posisi subordinat perempuan karena dianggap sebagai mahluk yang lebih lemah, lebih emosional dan tidak rasional (Jenainati \& Groves, 2007: 9). Setelah itu, feminisme dapat dibagi menjadi beberapa fase atau gelombang.

Feminisme gelombang pertama dianggap dimulai ketika Mary Wollenstonecraft membuat sebuah tulisan yang berjudul "The Vindication of the Rights of Woman" pada tahun 1792 di Inggris. Melalui tulisan ini, Wollstonecraft menyerukan pengembangan sisi rasional pada perempuan dan menuntut agar anak perempuan dapat belajar di sekolah pemerintah dalam kesetaraan dengan anak laki-laki. Selain masalah pendidikan, feminisme gelombang pertama juga ditandai dengan perjuangan perluasan kesempatan kerja bagi perempuan dan pemenuhan hak-hak legal perempuan dalam pernikahan maupun perceraian. Dalam pandangan beberapa ahli feminisme gelombang pertama mencakup beberapa ambivalensi (Gamble, 2006). Gerakan ini hanya memperjuangkan 
perempuan lajang dari kelas menengah saja, terutama yang memiliki intelektualitas tinggi. Sementara itu, gerakan mereka hanya ditujukan untuk isu-isu tertentu saja dan belum ada kesadaran mengenai gerakan feminisme yang lebih luas dan kritik yang paling mencolok adalah para feminis ini masih mengandalkan bantuan kaum laki-laki untuk mencapai tujuan-tujuan mereka (Suwastini, 2013: 200).

Feminisme gelombang kedua dimulai pada tahun 1960-an melalui buku yang ditulis Betty Friedan yaitu The Feminine Mystique pada tahun 1963 dan juga berdirinya National Organization for Woman pada tahun 1966 serta munculnya kelompok-kelompok conscious raising pada akhir dekade 60an (Gamble, 2006). Feminisme gelombang kedua feminisme gelombang kedua lebih memusatkan diri pada isu-isu yang mempengaruhi hidup perempuan secara langsung: reproduksi, pengasuhan anak, kekerasan seksual, seksualitas perempuan, dan masalah domestisitas (Gilis, 2004). Feminisme gelombang kedua ini terutama di Amerika Serikat kemudian berkembang menjadi dua aliran. Yang pertama adalah aliran kanan yang cenderung bersifat liberal yang bertujuan untuk memperjuangkan partisipasi perempuan di seluruh kehidupan sosial serta hak dan kewajiban yang sama dengan laki-laki. Sedangkan yang kedua adalah aliran kiri yang bersifat lebih radikal yang percaya bahwa kekuasaan patriarki bekerja pada insitusi-institusi personal seperti pernikahan, pengasuhan anak, dan kehidupan seksual (Suwastini, 2013: 201).

Berbagai kritik terhadap universalisme dalam feminisme gelombang kedua mendorong terjadinya pendefinisian kembali berbagai konsep dalam feminisme pada akhir tahun 1980an dan melahirkan feminisme gelombang ketiga sekaligus postfeminisme. Membedakan sekaligus menyamakan antara feminisme gelombang ketiga dan postfeminisme adalah persoalan yang cukup rumit. Jika keduanya dianggap berbeda, maka keduanya merupakan perkembangan yang berlangsung pada waktu yang hampir bersamaan. Jika keduanya dianggap perkemban- gan yang sama, ada usaha- usaha definitif dari beberapa feminis yang mendefinisikan diri secara berbeda (Suwastini, 2013: 202).

Dalam perkembangan pemikiran ilmu hukum, feminisme juga ikut mempengaruhi lahirnya pemikiran-pemikiran baru seputar hubungan hukum dengan hak perempuan, salah satunya adalah Teori Hukum Feminis (Feminist Legal Theory) yang muncul sekitar tahun 1970-an bersamaan dengan berkembangnya gerakan Critical Legal Studies di Amerika Serikat. Feminist Legal Theory yang biasa juga disebut feminist jurisprudence merupakan pemikiran yang berusaha melakukan terobosan terhadap berlakunya hukum terhadap perempuan dan diskriminasi yang didapat perempuan dari hukum. Dilihat dari tujuannya, Feminist Legal Theory lahir untuk memperjuangkan keadilan bagi perempuan yang tertindas, dan studi hukum seharusnya bukan hanya menerapkan asas kepastian tetapi amat terlebih asas keadilan (Setiawan, 2018: 127). Dapat dikatakan bahwa feminist legal theory adalah sebuah filsafat hukum yang didasarkan pada kesetaraan gender di bidang politik, ekonomi dan sosial.

Dalam pandangan feminist legal theory dalam sejarah, hukum merupakan instrumen untuk melanggengkan posisi wanita dibawah subordinasi kaum pria. Sejarah yang ditulis kaum pria telah menciptakan bias dalam konsep kodrat manusia, potensi dan kemampuan gender, serta budaya patriarki dalam pengaturan masyarakat. Budaya patriaki tersebut secara langsung maupun tidak langsung telah melahirkan diskriminasi gender, di mana kedudukan dalam hukum dan masyarakat dianggap lebih rendah dari kedudukan laki-laki. Karena itu, feminist legal theory berusaha untuk melakukan perubahan status kaum perempuan dengan merubah hukum dan pendekatannya dan pandangannya terhadap perkara gender menjadi lebih adil dan berimbang.

Secara langsung maupun tidak langsung pemikiran feminist legal theory telah mempengaruhi pemikiran hukum dalam setiap bidang hukum, diantaranya hubungan rumah tangga (domestic relations) seperti perkawinan, perceraian dan keluarga, kekerasan 
dalam rumah tangga, pekerjaan, pelecehan seksual, hak-hak sipil, perpajakan, dan hakhak reproduksi (Setiawan, 2018: 129).

Pada akhirnya, berbagai pemikiran yang berkenaan dengan feminisme tersebut merupakan usaha-usaha yang dilakukan untuk mewujudkan kesetaraan gender dan memastikan prinsip equality before the law, yaitu kedudukan setiap orang adalah sama di hadapan hukum tanpa membedakan gender, ras, status sosial seseorang, dan lain sebagainya.

\section{Metode Penelitian}

Sesuai dengan substansi permasalahan hukum yang hendak dikaji dalam penelitian ini, maka penelitian ini dirancang sebagai suatu penelitian yang bersifat normatif (dogmatik), terlebih khusus lagi adalah penelitian mengenai asas-asas hukum. Untuk mengkaji permasalahan yang ada maka penelitian ini menggunakan beberapa pendekatan, yakni: pendekatan peraturan perundang-undangan (statute approach), pendekatan komparatif (comparative approach), dan pendekatan konseptual (conseptual approach).

Data yang digunakan dalam penelitian ini tertuju pada data sekunder dan diperoleh melalui penelitian kepustakaan. Data yang didapatkan kemudian selanjutnya dianalisis secara kualitatif untuk menarik kesimpulan yang menjawab masalah yang dibahas sekaligus memberikan preskripsi berdasarkan argumentasi yang telah dibangun di dalam kesimpulan.

\section{Simpulan}

Sebagai salah satu bagian dari HAM, hak perempuan yang lahir dan berkembang dari pemikiran-pemikiran mengenai pentingnya perlindungan dan pemenuhan hak bagi kaum perempuan yang termasuk kelompok rentan pelanggaran HAM dan juga untuk memastikan kesetaraan gender. Hak perempuan yang telah diakomodasi dalam berbagai instrumen hukum nasional maupun internasional tersebut masih harus dijamin pemenuhannya secara de facto oleh setiap negara. Dalam pespektif filsafat hukum hal ini penting untuk memastikan bahwa kaum perem- puan mendapatkan keadilan sebagai tujuan tertinggi dari hukum itu sendiri dan memastikan bahwa prinsip equality before the law benar-benar berlaku tanpa ada halangan yang berasal dari diskriminasi gender.

\section{Daftar Pustaka}

Arivia, G. (2006). Feminisme: Sebuah Kata Hati. Jakarta: Kompas.

Asmarani, R. (2017). Perempuan dalam Perspektif Budaya. Sabda, 12 (1). 7-16.

Eddyono, S.W. (2020). Hak Asasi Perempuan Dan Konvensi CEDAW, < https://referensi.elsam. or.id/2014/09/hak-asasi-perempuan-dan-konvensi-cedaw/>

Flambonita, S. (2017). Perlindungan Hukum Terhadap Hak Pekerja Perempuan di Bidang Ketenagakerjaan. Simbur Cahaya. 24 (1). 4397-4424.

Gamble, S. (ed.). (2006). The Roudledge Companion to Feminisme and Postfeminism. London: Routledge.

Gillis, S., Howie, G. \& Munford, R. (2004). Third Wave Feminism: A Critical Exploration. Hampshire \& New York: Palgrave Macmillan.

Handayani, Y. (2020). Perempuan dan Hak Asasi Manusia, <https://rechtsvinding.bphn.go.id/ jurnal_online/20161014 PEREMPUAN\%20 DAN\%20HAK\%20ASASI\%20MANUSIA.pdf. >

Hasanah, U. \& Musyafak, N. (2017). Gender and Politics: Keterlibatan Perempuan dalam Pembangunan Politik, Sawwa, 12 (2). 409-431.

Jenainati, C. \& Groves, J. (2007). Introducing Feminism. Malta: Gutenberg Press.

Kania, D. (2015). Hak Asasi Perempuan dalam Peraturan Perundang-Undangan di Indonesia. Jurnal Konstitusi, 12 (4). 716-734.

Krisnalita, L.Y. (2018). Perempuan, HAM dan Permasalahannya di Indonesia. Binamulia Hukum, 7 (1). 71-81.

Machmudin, D.D. (2003). Pengantar Ilmu Hukum: Sebuah Sketsa. Bandung: Refika Aditama.

Marzuki, A. (2016). Penyelesaian Konflik Tenurial Kawasan Hutan Register 45 Mesuji Lampung Dalam Perspektif Keadilan. Disertasi Program Doktor Ilmu Hukum, Yogyakarta: Universitas Gadjah Mada.

Nasir \& Lilianti. (2017). Persamaan Hak: Partisipasi Wanita Dalam Pendidikan. Didaktis: Jurnal Pendidikan dan Ilmu Pengetahuan, 17 (1). 36-46.

Saparjaya, K.E. (dkk.). (2006). Laporan Akhir Kompedium Tentang Hak-Hak Perempuan. Jakarta: Badan Pembinaan Hukum Nasional Departemen Hukum dan HAM).

Savitri, N. (2008). Kajian Teori Hukum Feminis Terhadap Pengaturan Tindak Pidana Kekerasan Terhadap Perempuan dalam KUHP, Disertasi Program Doktor Ilmu Hukum. Bandung: Universitas Katolik Parahyangan

Setiawan, H. Ouddy, S. \& Pratiwi, M.G. (2018). Isu Kesetaraan Gender dalam Optik Feminist Juris- 
prudence dan Implementasinya di Indonesia. Jurisprudentie, 5 (2). 121-140.

Sinulingga, R. (2006). Gender Ditinjau Dari Sudut Pandang Agama Kristen. Jurnal Wawasan, 12 (1). 47-53.

Suwastini, N.K.A. (2013). Perkembangan Feminisme Barat Dari Abad Kedelapan Belas Hingga Posfeminisme: Sebuah Tinjauan Teoritis. Jurnal Ilmu Sosial dan Humaniora, 2 (1). 198-208.

Ujan, A.A. (2001). Keadilan dan Demokrasi: Telaah Filsafat Politik John Rawls. Yogyakarta: Kanisius.

Widiarty, W.S. (2017). Perlindungan Hukum Persamaan Hak Asasi Perempuan dalam Meningkatkan Perekonomian Indonesia. Tô-râ. 3 (3). 639-646. 